\title{
Challenges of Teachers in an Effective Rural Secondary School in Mexico
}

\author{
Cristóbal C. Ramón ${ }^{1}$, Rubí S. Peniche ${ }^{1} \&$ Edith Cisneros-Cohernour ${ }^{2}$ \\ ${ }^{1}$ Department of Education, Autonomous University of Aguascalientes, México \\ ${ }^{2}$ Faculty of Education, Autonomous University of Yucatán, México \\ Correspondence: Rubí S. Peniche, Department of Education, Autonomous University of Aguascalientes, México. \\ Av. Universidad No. 940. E-mail: rupeniche81@gmail.com
}

Received: August 17, 2018 Accepted: October 2, 2018 Online Published: December 30, 2018

doi:10.5539/jel.v8n1p143 URL: https://doi.org/10.5539/jel.v8n1p143

\begin{abstract}
This paper examines from the perspective of teachers the problems faced by a telesecondary school for the achievement of its educational objectives, as well as the implemented actions to overcome their problems, located in the state of Yucatan, Mexico. A case study was carried out, selected on the basis of the good results obtained by students in the ENLACE test, belonging to a highly marginalized context. The methodological and data triangulation allowed to verify and validate data, obtained through interviews, focus groups, documentary analysis and qualitative observation. The results indicate that there are individual and general factors that need to be considered to improve the students' education: lack of effectiveness in the development of educational policy programs, lack of some resources and infrastructure, lack of technological resources, teachers training and management of the school center. The strategies the school makes to address these problems are helping to improve student performance.
\end{abstract}

Keywords: marginalization, rural environment, school effectiveness, telesecondary school

\section{Introduction}

In Mexico, as in other Latinamerican countries, an interest has increased about the quality of schools, mainly due to identified problems in students' performance and results. According to the National Institute of Educational Evaluation [INEE] (2010a and 2010b) the problems of education in this country, such as the poor quality of results in the assessments, educational lag (caused by high rates of failure and school dropping) emphasize in the level of secondary education, the last section of obligatory basic education.

In the same way, secondary school students' performance is even lower when the school is located outside the main cities. According to National Institute of Statistics and Geography [INEGI] (2010), the population living in rural areas shows higher rates of marginality and demand for services.

Although there are a large number of studies carried out on secondary education, little research has been made about the modality of telesecondary: Telesecondary is a school modality in the Mexican Educational System that offers secondary education to young people who live mainly in small, marginalized rural communities. A peculiarity of this modality is that a teacher is responsible of teaching all subjects contained in the curriculum corresponding to a grade level, unlike other modalities where each class is taught by different teachers. In general, schools in this modality show a lack of support for administrative work, responsibility that has to be assumed by teachers and students and, at least as former proposal, these schools must have audiovisual and computer resources to support the different taught subjects. When it comes to telesecondaries with until three school groups, one of the teachers is designated as a school responsible, which implies that this same teacher must perform functions as professor in front of a class and as a principal, with its corresponding administrative and management functions, the school, with the school community and with the authorities of this modality.

The incipient research on telesecondaries indicates that these educative centers report the lowest level of academic achievement and other problems in relation to teacher training and responsibilities. Calixto \& Rebollar (2008) affirm that poor results in these schools may be due the fact that teachers, in addition to their educational responsibility, need to perform administrative tasks and, even if they have mastered the disciplinary field, they must teach more subjects than those they correspond to the school grade they attend, a situation that is 
complicated when a teacher works with more than one grade. On the other hand, Santos (2004), affirms that some of the problems faced by these schools are: lack of permanent update and training programs for teachers, inadequate school facilities, delay or even lack in the delivery of bibliographic and audiovisual materials, malfunction of the television signal and deficit of teaching personnel to attend the service as it raises; also, the lack of commitment from some teachers with the educational activities carried out with the students, and abscency to linking actions that are organized with parents and community members.

Conducting research in telesecondaries is needed both in those with poor performance, and even more in cases of schools that have achieved the expected results while being in conditions of marginality. As asserted by Kalman and Carvajal (2007), there have been no studies related to the school environment aimed to these educational centers, collegial work among teachers, students, managers or how the teaching and learning processes are carried out.

\subsection{Purpose and Research Questions}

The research design by case study in which this paper is based, is focused on a telesecondary in the southeast of Mexico located in a context of high marginality and high diversity, and whose students have achieved the expected results in the standardized tests, specially in the ENLACE test. The objective of the study was to examine, from the perspective of the main school actors, the problems and challenges telesecondaries deal with to achieve their educational objectives, as well as the actions they have implemented to overcome them. For the purposes of this document, partial findings of the study will be presented that are determined in the following research questions, specifically focused on the teaching staff.

What are the problems and challenges teachers of a telesecondary school face in order to achieve their objectives?

What actions have the teachers of a telesecondary implemented to overcome the conditions and problems they face?

\subsection{Importance of the Study}

Achieving school effectiveness does not depend exclusively on the changes established by the educational authorities nor the distribution of new materials to improve teaching or training. To achieve improvement in schools' quality, it is fundamental to establish and implement strategies based on the diagnosis of their operation and to know their needs and possibilities; the quality of education, so says Buenfil (2000), depends on everyone's participantion in the process, identifying the problem, knowing its causes, looking for solutions and new options to obtain better results.

It is here where the importance of this research is denoted, since its results would provide information regarding on how they conceptualize, interpret, live and seek to overcome educational problems and challenges the different educational actors of teleseccondaries located in marginalized areas, information still not available from the researches related to the subject. Based on this, useful information will be available for decision-making for educational authorities, government authorities and the educative actors themselves, to improve the quality of education.

By providing information on the context and conditions under which telesecondaries in the state of Yucatan operate, this document also contributes to the importance of issues that are so important and poorly addressed, such as social equity, as well as the generation of educational policies according with these contexts.

\section{Methodology}

This research was developed through a naturalistic approach, because it was considered important to reflect and interpret the educational reality to reach the understanding or transformation of the described reality, based on the meaning attributed by people who creates it (Bisquerra, 2009). The single case study was used in its intrinsic modality (Stake, 1994), which allowed examining the particularity and complexity of a single case to understand its incidence in important circumstances; as specific techniques for obtaining information, individual semi-structured interviews, observation, focus groups and document analysis were used. The recording of the data was done through audio recording and taking notes, always with the consent of participants, their parents or thutors in the cases of students. The analysis of the results was carried out via content analysis, allowing to determine the problems and challenges of telesecondary, as well as the actions through which it has tried to overcome them.

Two triangulation strategies were used, this being an effort to see if observation results and participants' reports contained the same meaning when it is found in other circumstances (Stake, 2010). The types of triangulation used 
in this research were the methodological and the data, because as Denzin (1989) mentions, the first one allows the involvement of different methods, obtaining the vision of the phenomenon from different perspectives; and the second one allows considering different data sources.

For this study, a telesecondary from eastern Yucatan, Mexico, located in a higly marginalized area was selected, considered as a unique case study. As stated by Creswell (2009) and Bisquerra (2009), the selection of the school was based on particular criteria, being that the school had a head of school and a teacher responsible for each grade level, that the school was located in a rural community with a high degree of marginalization, that the inhabitants of the community are mostly Mayan speakers and that the students have obtained prominent results in the ENLACE test in recent years, an aspect that is relevant to consider a school as an effective one.

This research involved each of the teachers who taught in the three school grades of the teleseccondary, one which also played the role of head of the school. Also, second and third grade students were included, which together were a total of twenty-two: eleven from second grade (seven female and four male students) and eleven from third grade (two female and nine male students). The decision to include last grades students and not the ones in first grade was since the last ones had been part of the school only for a month to the date of the focus groups implementation and could not provide enough information for he purposes of the research. Participant students were between twelve and sixteen years old.

The rural community where the school is located and has a total population of 429 inhabitants (INEGI, 2010), of whom 200 are female and 229 male, in a total of approximately 118 houses; the population mainly performs agricultural activities. The percentage of illiteracy among adults is $24.08 \%$ and the average level of education is below the $5^{\text {th }}$ grade of elementary school. From the $81 \%$ of the population which is indigenous, $44 \%$ speaks an indigenous language additional to spanish, and $17 \%$ speaks an indigenous language but does not speaks Spanish.

\section{Results}

The problems identified by the teachers go from those that refer to the very poor conditions of the context, given that the community is classified as highly marginalized, to the lack of effectiveness of the Federal programs that should have a positive impact on student achievement. Below are the difficulties that the teachers manifested, accompanied by some quotes as evidences of such experiences. The main challenges described by the teachers interviewed in the study are described below:

\subsection{Teacher Challenges}

Lack of effectiveness in the development of educational policy programs, both in planning and execution, such as the digital skills for all programs:

"So, books are made for the whole country and piloted..., electronic books... for first grade, next year the ones for second grade. They were not delivered. Government change comes, and they say: It's over, HDT disappears, it will no longer be" (Mr. Antonio).

Lack of some resources and infrastructure, as there is no administrative and concierge staff available:

"We have to do the work, we do not have people here..."

Lack of technological resources. Teacher Oscar alludes to the fact that they do not have a satellite television signal:

“... the satellite antenna... is not fulfilling its function, the parales are rotted. Annually I report that I have no EDUSAT signal".

Lack of update to support teaching books:

"And then we started to take the 2011 plan, with the books, because they were outdated, that is, our books are from 2009, and the plan that is being carried out is from 2011, because we were supposed to have books with HDT "(Teacher Antonio).

Teacher training. In some cases, teachers do not have enough experience to transmit the contents effectively to students:

“... the Evaluation Center starts to hire, that is, does a small 'assessment', supposedly, not a selection; and the CEDE sends all its advisors... they are inexperienced guys..."

Management of the school center. Specific training is required for function performance; and there is duality of functions (both as responsible and as a class teacher), which can affect the effectiveness in the performance of both functions: 
"To tell the truth it is quite enough, I've been responsible for ten years, I've tried to throw the towel, it's too much work, it is stressing because, since I'm talking about what it's like to give my classes, it's, I'll make it clear for you: first to keep all the paperwork up to date, to answer all the information. " (Mr. Oscar)

When Oscar was asked about the training he received, he answered in a concrete way:

"There is no training. I assume the position, I put myself in the least attractive situation of my life, if you want to call it that, the truth (smiles). There we go."

Lack of prerequisites for the level of schooling. In the opinion of the teacher Georgina:

"The boy comes with a low level. It gives us a lot of work here at school to level them up... the children come that God, God... there you are giving and giving, struggling, struggling a good among of time the first-grade teacher is dedicated to see multiplications, readings, all that with elementary school children, which should not be our work anymore".

Furthermore, the absence of parents at home is an obstacle to the achievement of school goals, as it forces students to look for a paid job, which limits their chances of making the most of their studies:

"The lack of parents. Otherwise, you need to work ... for school, to achieve what you want ... and earn yourself a living "(Angel).

Apparently, the problems (attributable to the characteristics or effort of the students) mentioned by the teachers were, mainly, failing the grade, abuse in the use of technology, those of a personal nature, the motivation to study and the lack of prerequisites.

One of the main problems and challenges is that in the teleseconday, unlike other modalities, the teacher is responsible for teaching all the subjects included in the curriculum to the same group in charge of, which makes teachers' work more demanding, and therefore training should be aimed at providing teachers with the tools and content necessary to improve their performance.

\subsection{Actions to Solve Problems}

In view of the previous challenges, a series of strategies are presented that the educational actors stated to implement:

- For the teachers who work in the school, the initiative, the team work and the commitment they have are the main virtues that have allowed them to address some of the problematic situations they face as a school. Teacher Georgina:

"... the courses are already, I think, more appropriate, really, so what you learn you use it, you transmit it to the boys, and that knowledge gets to be really useful... the courses are more appropriate."

- Quality Schools Program (PEC), the contribution of the PEC in relation to the attention of training needs of students, specifically in the Information Technology area, is described by the teacher Antonio:

“... seeing the need, then with the PEC all that equipment could be bought, and it's there, around 11, 15 computers, which have been repaired, boots... I mean, with it, with the PEC".

- Construction of classrooms by the municipality government, particularily the computer classroom. From the PEC a smaller contribution was destined for this purpose.

Support for students with lack preparation through the delivery of a propaedeutic course:

"It's twenty effective days of class. And that is one of the strategies that is used to level and compensate that level with which they come..." "(teacher Oscar).

- Development of materials and resource: Teachers have also designed compendiums of exercises to complement the former textbooks of telesecondary, and thus accomplish what is established in the 2011 curriculum, as well as providing material to students, for free.

Establishing a link with teachers from other high schools, whose books are aligned with the former curriculum, with the purpose of getting books for their students. Teacher Oscar mentions:

"... we are now in contact with some teachers... so that, let's say, he separates for us a lot of books, and we ask them to talk to the students and their old books, say... Well, we need between 12 or 13 here, right? In other words, we talk to 20 students, who offer them I do not know, for $\$ 50.00$ pesos [ $\$ 2.5$ dollars] each pack of books to give it to us."

With the above, it is remarkable the work of a teacher at the basic level, specifically telesecondary, is surrounded 
by multiple factors that can keep from its correct functioning, causing the poor learning results that have already been known in recent decades. Even with this panorama, the cause is not lost; studies of this type try to show what is going on in those contexts, trying to obtain sensitivity from the scientific community as well as politicians.

\section{Conclussions}

Efficacy studies are quite relevant for current education, considering that the deep exploration of factors that determine effective results is needed; as Pedroza, Peniche and Lizasoain (2018) correctly point out, it is not enough to quantify results of school performance without inquireing the reasons for those behavoirs. It is of special interest to address school issues in situations of vulnerability, specially when dealing with indigenous communities, where the application of science must be more sensitive (Peniche \& Ramón, 2018).

One of the main problems faced by the school actors is linked to teacher training, given the selection of instructors does not follow criteria according to the needs and experience of teachers and heads of schools.

Educational policies, although they are proactive and show ambition, need to be accompanied by the technological needs and equipment requirements that ensure their correct implementation. The effectiveness in programs implementarion derived from educational policies, linked to educational reforms, also affects the effectiveness with which schools can achieve their objectives, as the case of the Digital Skills for All program. This is the opinion of the professors who participated in the study, an opinion that agrees with the results obtained in the research of Cisneros-Cohernour, López and Canto (2007), focused on identifying the conditions that affect the teaching of sciences in High Schools of Yucatan: According to these authors, secondary teachers mentioned that educational reforms are not accompanied by the necessary resources for their implementation, especially when it comes to the use of technology for teaching and learning.

In a similar sense, Martínez-Otero (2009) adds that, along the obtention of technological and material resources, it is essential to train education actors in the proper use of these resources, given that either the lack, misuse or abuse of them could adversely affect the effectiveness of the programs. Therefore, the implementation of this type of program should include a context condition analysis and other characteristics that influence the performance of students, such as previous education or socioeconomic level, because when they are not appropriate they can limit the expected use in the students as some of them fail to meet their basic nutritional needs.

The management is demanding and the training and necessary material and human resources that could allow an optimal operation of the school are not granted. Among the options to overcome the problems of the school are the teachers' initiative and the person in charge, and the teamwork with municipal authorities and other schools.

A factor identified as limiting to the achievement of the objectives of the schools is the lack of human, material and technological resources, specially in telesecondaries located in rural communities highly marginalized. This situation was referred since 2007, through a report made by García, Benítez, Huerta, Medina and Ruiz for INEE. It shows that more than half of the schools in these communites do not have services such as water closedrooms, running water or furniture's poor condition; it also shows infrastructure is inadequate, since there are no laboratories and the few that exist have to be used as classrooms. In addition, $15 \%$ of schools do not have a satellite dish to receive the signal, $12 \%$ do not have enough television sets, which represents a great concern, since the use of educational television is considered the main feature of this modality.

Miranda and Reynoso (2006) conclude in their research that carring out of changes for school's management improvement requires, more than the arrangement of material, economic and human resources, an institutional commitment, which requires the participation of diverse actors and the integration of multiple wills. For this reason, it is very important to consider that until now this problem is still valid, with no solution yet, at least for the case studied, so greater efforts must be made to address it. It should be noted that since the study by García et al (2007) a presidential period has already finished, and another is already halthrough, in which two educational reforms derived from national policy programs have also been implemented.

The role of school principals occupies a central position in the effectiveness in which educational objectives are achieved in schools. Its function is to integrate the efforts of every educational actor, such as students, teachers, parents mainly, as well as to arrange social programs and resources from governmental and educational authorities of the modality. Therefore, their training and update should focus on the development of administrative functions, rather than pedagogical functions, to achieve a better school functioning, as Sandoval (2007) concludes in his research. Because in the telesecondaries some principal's functions are double, as school responsible and as class teachers, the solution becomes more challenging, since the principals only receive from 
the corresponding instances the training aimed to improve their pedagogical skills as any other professor, still pending the necessary specific training for the performance of the directive function.

It is important to emphasize that the effectiveness of schools is achieved by considering that they are part of a global school system, as mentioned by Fullan (2005). Thus, it must be considered that the school is part of a larger context, and its objectives can only be achieved if the integration of three levels is achieved: the school / community, the district or region, and the government politics level.

Telesecondary modality in the Mexican Educational System represents a great opportunity for students from marginalized communities to complete the corresponding studies of basic education proposed in Mexico.

\section{References}

Bisquerra, R. (2009). Metodología de la investigación educativa (2nd ed.). Madrid: La Muralla.

Calixto, R., \& Rebollar, A. (2008). La telesecundaria ante la sociedad del conocimiento. Revista Iberoamericana de Educación, 44(7), 1-11.

Cisneros-Cohernour, E. J., López, M., \& Canto, P. J. (2007). Condiciones de la enseñanza de las ciencias en Yucatán. In E. Cisneros-Cohernour (Ed.), La enseñanza de las ciencias en escuelas secundarias de Yucatán Cuestiones críticas, retos y posibles soluciones (pp. 27-42). Mérida: Consejo Nacional de Ciencia y Tecnología-Universidad Autónoma de Yucatán.

Creswell, J. (2009). Research Design. Qualitative, Quantitative, and Mixed Methods Approaches (3rd ed.). USA: SAGE.

Denzin, N. (1989). The Research Act (3rd ed.). USA: Prentice Hall.

Fullan, M. (2005). The Tri-Level Solution. Education Analyst. Society for the Advancement of Excellence in Education.

García, A., Benítez, Y., Huerta, E., Medina, N., \& Ruiz, G. (2007). Infraestructura escolar en las primarias y secundarias de México. Instituto Nacional para la Evaluación de la Educación. México: INEE.

Instituto Nacional de Estadística y Geografía. (2010). Censo de Poblacion y Vivienda 2010. Obtenido de http:www.inegi.org.mx

Instituto Nacional para la Evaluación de la Educación. (2010a). El derecho a la educación en México. México: INEE.

Instituto Nacional para la Evaluación de la Educación. (2010b). Panorama de la educación en México. La educación básica 2009. México: INEE.

Kalman, J., \& Carvajal, E. (2007). Hacia una contextualización de la enseñanza y el aprendizaje en las aulas de la Telesecundaria. Revista Latinoamericana de Estudios Educativos, 37(3\&4), 69-106.

Martínez-Otero, V. (2009). Diversos condicionantes del fracaso escolar en la educación secundaria. Revista Iberoamericana de educación, 67-85.

Miranda, F., \& Reynoso, R. (2006). La reforma de la educación secundaria en México. Elementos para el debate. Revista Mexicana de Investigación Educativa, 11(31), 1427-1450.

Pedroza, L. H., Peniche, R. S., \& Lizasoain, L. (2018). Criterios para la identificación y selección de escuela eficaces de nivel medio superior. Revista Electrónica de Investigación Educativa, 20(1), 14-25. https://doi.org/10.24320/redie.2018.20.1.2170

Peniche, R. S., \& Ramón, C. C. (2018). Academic Performance and Experiences of Maya College Students in Yucatan, Mexico. Alteridad, 13(1), 115-125. https://doi.org/10.17163/alt.v13n1.2018.09

Pieck, E. (2005). La secundaria técnica. Su contribución a la formación para el trabajo en sectores de pobreza. Revista Mexicana de Investigación Educativa, 10(25), 481-507.

Sandoval, E. (2007). La reforma que necesita la secundaria mexicana. Revista Mexicana de Investigación Educativa, 12(32), 165-182.

Santos, A. (2004). Situación actual de la telesecundaria mexicana. Revista Educación, 2001(11), 27-32. 


\section{Copyrights}

Copyright for this article is retained by the author, with first publication rights granted to the journal.

This is an open-access article distributed under the terms and conditions of the Creative Commons Attribution license (http://creativecommons.org/licenses/by/4.0/). 